\title{
Influence of salt concentration on the characteristics of Beyaz cheese, a Turkish white-brined cheese
}

\author{
Mehmet GUVENa, Sebnem YeRLIKAYA ${ }^{\mathrm{a}}$, Ali A. HAYALOGLU ${ }^{\mathrm{b} *}$ \\ a Department of Food Engineering, Agricultural Faculty, Cukurova University, 01330 Adana, Turkey \\ b Department of Food Engineering, Engineering Faculty, Inonu University, 44280 Malatya, Turkey
}

Received 14 February 2005 - Accepted 28 July 2005

\begin{abstract}
Beyaz cheese (Turkish white-brined cheese) was ripened in four different brines with $12,14,16$ or $18 \mathrm{~g} \mathrm{NaCl} \cdot 100 \mathrm{~g}^{-1}$ water (w/w) at $7 \pm 1{ }^{\circ} \mathrm{C}$ for 9 weeks. The effect of $\mathrm{NaCl}$ concentration on gross composition, proteolysis, sensory characteristics and hardness of the cheeses were investigated during ripening. The cheeses ripened in varying concentrations of $\mathrm{NaCl}$ differed in $\mathrm{pH}$ values, dry matter, total protein, hardness $(\mathrm{mm} / 5 \mathrm{~s}), 12 \%(\mathrm{w} / \mathrm{v})$ trichloroacetic acid-soluble nitrogen fraction and hydrolysis of $\beta$-casein, but they did not differ in water-soluble nitrogen or hydrolysis of $\alpha_{\mathrm{s} 1}$-casein. The cheeses ripened in a $12 \mathrm{~g} \mathrm{NaCl} \cdot 100 \mathrm{~g}^{-1}$ brine had the best flavour score and overall acceptability by the panellists. The results obtained from this study indicated that increase in $\mathrm{NaCl}$ concentration in brine (more than $14 \mathrm{~g} \cdot 100 \mathrm{~g} \mathrm{~g}^{-1}$ ) is correlated with lower levels of proteolysis and overall acceptability in Beyaz cheese.
\end{abstract}

Beyaz peynir / white cheese / brine / proteolysis / ripening

摘要 - 盐浓度对土耳其白卤干酪一Beyaz干酪特性的影响。在 $7 \pm 1^{\circ} \mathrm{C}$ 下将 Beyaz干酪 (土耳 其白卤干酪）分别放 12、14、16、18 g NaCl$\cdot 100 \mathrm{~g}^{-1}$ 水 (w/w) 的盐浓度中成熟 9 周。研究 了成熟过程中 $\mathrm{NaCl}$ 浓度对干酪总成分、蛋白质水解、感官特性和硬度的影响。在成熟期间 随着 $\mathrm{NaCl}$ 浓度不同, 表现在干酪的 $\mathrm{pH}$ 、干物质、总蛋白质、硬度 $(\mathrm{mm} / 5 \mathrm{~s}) 、 12 \%(\mathrm{w} / \mathrm{v})$ 三 氯乙酸可溶性氮含量和 $\beta$ - 酪蛋白的水解都发生了变化, 但是水溶性氮和 $\alpha_{\mathrm{s} 1}$ - 酪蛋白水解量 并没有改变。经感官评定, 在 $12 \mathrm{~g} \mathrm{NaCl} \cdot 100 \mathrm{~g}^{-1}$ 盐水中成熟的干酪风味最佳。试验结果表 明 $\mathrm{NaCl}$ 溶液浓度越高 (高于 $14 \%$ ), Beyaz 干酪的水解程度越低, 总体接受性越差。

Beyaz 干酪 / 白卤干酪 / 盐水 / 蛋白水解 / 成熟

Résumé - Influence de la concentration en sel sur les caractéristiques physicochimiques du Beyaz peynir maturé. Du Beyaz peynir (fromage turc saumuré) a été conservé durant neuf semaines dans des saumures de quatre concentrations en sel différentes $\left(12,14,16\right.$ ou $\left.18 \mathrm{~g} \mathrm{NaCl} \cdot 100 \mathrm{~g}^{-1}\right)$ à $7 \pm 1{ }^{\circ} \mathrm{C}$, dans le but d'étudier l'effet de la concentration en sel durant la maturation sur la composition, la protéolyse, la texture et les caractéristiques sensorielles du fromage. Des différences significatives ont été constatées pour les valeurs de $\mathrm{pH}$, de la matière sèche, de la teneur en protéine totale, la dureté, la fraction d'azote soluble dans l'acide trichloroacétique à $12 \%(\mathrm{w} / \mathrm{v})$, et l'hydrolyse de la caséine $\beta$, tandis qu'aucune différence n'a été observée pour la quantité d'azote soluble

\footnotetext{
* Corresponding author (通讯作者): ahayaloglu@inonu.edu.tr
} 
dans l'eau et l'hydrolyse de la caséine $\alpha_{\mathrm{s} 1}$. Les fromages maturés dans la saumure à $12 \%$ de sel ont obtenu les meilleurs scores pour la flaveur et l'acceptabilité globale. Les résultats obtenus dans cette étude montrent que la protéolyse et l'acceptabilité globale des fromages Beyaz peynir sont moins élevées pour les fromages maturés dans des saumures de concentrations en sel supérieures à $14 \%$.

Beyaz peynir / fromage / saumure / protéolyse / maturation

List of abbreviations: ANOVA: analysis of variance; LSD: least significant difference; TCA-SN: 12\% trichloroacetic acid-soluble nitrogen; urea-PAGE: urea-polyacrylamide gel electrophoresis; WSN: water-soluble nitrogen.

\section{INTRODUCTION}

Beyaz cheese or Turkish white-brined cheese is the most popular cheese variety in Turkey. It has a semi-hard texture, and a salty and acid taste [16]. Salting is an essential process in the cheese, since salt has a major effect on the control of microbial growth, the removal of whey from the cheese matrix, and the development of the characteristic flavour and texture of the cheese through the control of the biochemical pathways, i.e., proteolysis, lipolysis and glycolysis [14, 15, 32].

The salt concentration of the brine used for ageing of Beyaz cheese in Turkey varies widely. Yildiz et al. [33] reported that the salt concentrations used for Beyaz cheese manufacture in four different dairies ranged from 8.5 to $23.5 \mathrm{~g} \mathrm{NaCl} \cdot 100 \mathrm{~g}^{-1}$. In brined cheeses such as Beyaz cheese, $\mathrm{NaCl}$ diffuses from the surface to the centre of cheese until it reaches uniformity of distribution $[14,15]$. During cheese ripening, milk proteins are converted by proteolysis into water-soluble nitrogenous fractions such as peptides of various molecular weights and amino acids, which contribute to the development of flavour and texture in cheese [10]. Proteolysis in cheese depends on the salt-in-moisture level of the cheeses. Increasing the level of salt in brine can negatively affect the proteolysis in cheese. To the authors' knowledge, information on the effect of salt concentration on Beyaz cheese quality is limited, especially on proteolysis during ripening [30]. Therefore, it would be interesting to investigate the impact of $\mathrm{NaCl}$ concentration on proteolysis of Beyaz cheese. This paper presents the evaluation of chemical composition, nitrogen fractions, the urea-PAGE patterns and the sensory properties of Beyaz cheese during 9 weeks of ripening.

\section{MATERIALS AND METHODS}

\subsection{Cheese-making}

Beyaz cheese was manufactured from pasteurised cow's milk in duplicate. The cheese milk was acidified by using a commercial mesophilic starter culture (MA 014, Rhodia, Dangé-St-Romain, France). Food-grade calcium chloride (Merck, Darmstadt, Germany) and liquid calf rennet (Peyma-Hansen, Istanbul, Turkey) were used in the manufacture of Beyaz cheese. The cheese was manufactured according to the standard method for Beyaz cheese as described by Hayaloglu et al. [16]. Samples were ripened in brines containing $12 \mathrm{~g}$ $\mathrm{NaCl} \cdot 100 \mathrm{~g}^{-1}$ (cheese A), $14 \mathrm{~g} \mathrm{NaCl} \cdot 100 \mathrm{~g}^{-1}$

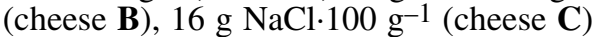
and $18 \mathrm{~g} \mathrm{NaCl} \cdot 100 \mathrm{~g}^{-1}$ (cheese D) at $7 \pm$ $1{ }^{\circ} \mathrm{C}$ for 9 weeks and the samples were taken after 1, 3, 6 and 9 weeks of ripening.

\subsection{Compositional analysis}

Cheeses were analysed in duplicate during ripening for moisture by the oven-drying method at $102 \pm 1{ }^{\circ} \mathrm{C}$ [17], salt by the Mohr method [23], fat by the Van GulikGerber method [6] and total nitrogen contents by the Kjeldahl method [18]. The $\mathrm{pH}$ of cheeses was measured using a $\mathrm{pH}$ meter 
(WTW, Weilheim, Germany) in a slurry prepared by dispersing $10 \mathrm{~g}$ of grated cheese in $10 \mathrm{~mL}$ of deionised water.

\subsection{Assessment of proteolysis}

Water-soluble nitrogen (WSN) of the cheese was prepared according to Kuchroo and Fox [21], 12\% trichloroacetic acid-soluble nitrogen (TCA-SN) fractions were determined by the method of Polychroniadou et al. [27]. Urea-polyacrylamide gel electrophoresis (urea-PAGE) of the cheeses was performed using a Mini Protean III vertical slab gel unit (Bio-Rad Laboratories Ltd., Watford, UK) according to Andrews [5]. Preparation of cheese samples for electrophoresis and running conditions at $300 \mathrm{~V}$ were according to Fenelon and Guinee [9]. Twenty mg of cheese were dissolved in 1 $\mathrm{mL}$ of sample buffer and incubated at $55^{\circ} \mathrm{C}$ for $10 \mathrm{~min}$. The gels were stained directly by the method of Blakesley and Boezi [7] with Coomassie Brilliant Blue G-250. The gels were scanned at $590 \mathrm{~nm}$ using a densitometer (Clinicscan 2, Helena Laboratories, Texas, USA). The optical density of each band or group of bands was expressed as a percentage of the optical density of the total bands.

\subsection{Sensory evaluation and determination of hardness}

The cheeses were graded at 1, 3, 6 and 9 weeks of ripening by seven graders (from the permanent staff at the Food Engineering department) familiar with Beyaz cheese. They graded the cheeses for appearance (scale 0-20), body and texture (scale 0-35), odour (scale 0-10) and flavour (scale 0-35) according to the Turkish Standards for Beyaz cheese as described in TSE [29]. Graders were asked to put the cheeses in order according to their overall quality or general acceptability. Hardness of the cheese samples was determined by a penetrometer (PNR 6, Sur, Berlin, Germany) using a conical form probe with a weight of $94.4 \mathrm{~g}$. The penetration time of the probe into the cheese sample was $5 \mathrm{~s}$. Five readings were taken per sample and hardness was expressed in $\mathrm{mm} / 5 \mathrm{~s}$.

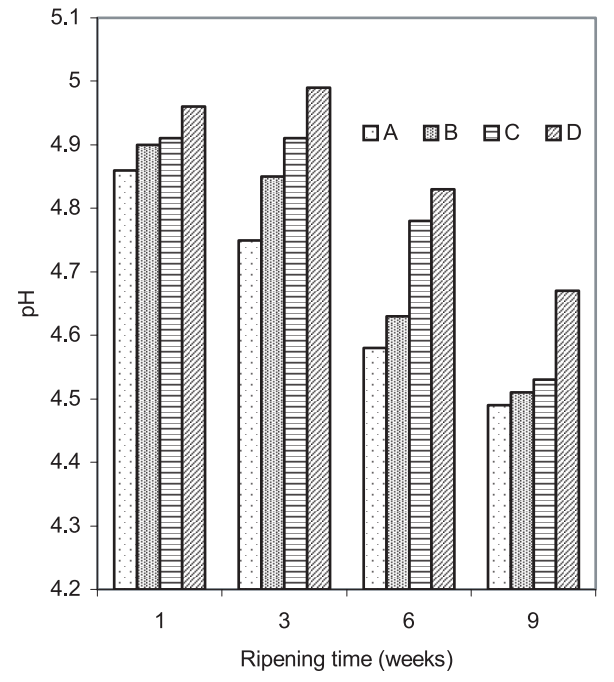

Figure 1. Changes in $\mathrm{pH}$ values of Beyaz cheeses ripened in brines of 12 (A), 14 (B),

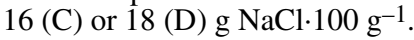

\subsection{Statistical analysis}

Data were analysed by means of analysis of variance (ANOVA). The means were compared by the least significant difference (LSD) test at $P<0.05$ using the SPSS 10.0 software package [28].

\section{RESULTS AND DISCUSSION}

\subsection{Gross composition}

Salting of cheese can influence the cheese $\mathrm{pH}$ due to its effect on microbial activity. Low levels of salt can stimulate bacterial activity; however, concentrations $>2.5 \%$ have a negative effect [15]. The influence of different concentrations of $\mathrm{NaCl}$ on the $\mathrm{pH}$ values of the cheeses during ripening is shown in Figure 1. Differences among the cheeses were significant $(P<0.05)$ during ripening. The lowest and highest level of $\mathrm{pH}$ values were observed in the cheeses ripened in brines containing $12 \mathrm{~g} \mathrm{NaCl} 100 \mathrm{~g}^{-1}$ or $18 \mathrm{~g} \mathrm{NaCl} 100 \mathrm{~g}^{-1}$, respectively. These results suggest that 
Table I. Chemical composition of Beyaz cheeses ripened in brines with different $\mathrm{NaCl}$ concentrations (Trials 1 and 2).

\begin{tabular}{|c|c|c|c|c|c|c|c|c|c|}
\hline \multirow[b]{3}{*}{ Parameter } & \multirow[b]{3}{*}{$\begin{array}{l}\text { Time } \\
\text { (wks) }\end{array}$} & \multicolumn{8}{|c|}{ Cheeses } \\
\hline & & \multicolumn{2}{|c|}{$\mathrm{A}^{1}$} & \multicolumn{2}{|c|}{$\mathrm{B}^{1}$} & \multicolumn{2}{|c|}{$\mathrm{C}^{1}$} & \multicolumn{2}{|c|}{$\mathrm{D}^{1}$} \\
\hline & & $\mathrm{T} 1$ & $\mathrm{~T} 2$ & $\mathrm{~T} 1$ & $\mathrm{~T} 2$ & $\mathrm{~T} 1$ & $\mathrm{~T} 2$ & $\mathrm{~T} 1$ & $\mathrm{~T} 2$ \\
\hline \multirow[t]{4}{*}{ Dry Matter (\%) } & 1 & 33.15 & 32.79 & 35.96 & 34.29 & 34.00 & 34.86 & 34.10 & 35.84 \\
\hline & 3 & 35.12 & 34.26 & 35.35 & 35.52 & 35.38 & 35.67 & 35.93 & 37.28 \\
\hline & 6 & 33.78 & 35.04 & 35.50 & 35.01 & 34.18 & 35.87 & 37.36 & 35.99 \\
\hline & 9 & 35.06 & 34.08 & 36.41 & 36.03 & 37.91 & 36.64 & 37.51 & 38.58 \\
\hline \multirow{4}{*}{$\begin{array}{l}\text { Fat-in-Dry Matter } \\
(\%)\end{array}$} & 1 & 42.20 & 43.01 & 42.02 & 40.28 & 45.76 & 41.65 & 45.46 & 41.85 \\
\hline & 3 & 40.57 & 40.86 & 41.72 & 43.58 & 41.72 & 42.75 & 42.25 & 39.61 \\
\hline & 6 & 44.16 & 43.68 & 42.86 & 39.42 & 38.05 & 40.44 & 38.15 & 38.20 \\
\hline & 9 & 39.93 & 44.84 & 39.55 & 41.40 & 39.55 & 39.58 & 39.33 & 40.86 \\
\hline \multirow[t]{4}{*}{ Protein $(\%)$} & 1 & 13.14 & 12.92 & 13.57 & 14.04 & 13.23 & 12.78 & 13.38 & 13.37 \\
\hline & 3 & 13.40 & 13.84 & 14.28 & 13.57 & 13.01 & 13.95 & 13.22 & 14.62 \\
\hline & 6 & 13.71 & 13.77 & 13.84 & 15.51 & 14.17 & 13.07 & 13.21 & 13.85 \\
\hline & 9 & 14.78 & 14.47 & 15.42 & 14.55 & 14.93 & 14.92 & 14.83 & 15.52 \\
\hline \multirow{4}{*}{$\begin{array}{l}\text { Salt-in-Moisture } \\
\text { (\%) }\end{array}$} & 1 & 4.29 & 4.37 & 4.27 & 3.86 & 4.54 & 4.85 & 5.46 & 6.44 \\
\hline & 3 & 4.50 & 4.78 & 5.28 & 5.00 & 5.96 & 6.09 & 6.76 & 6.35 \\
\hline & 6 & 5.60 & 4.91 & 4.63 & 4.92 & 6.61 & 6.47 & 7.38 & 8.06 \\
\hline & 9 & 5.38 & 5.72 & 5.91 & 5.63 & 6.78 & 6.42 & 6.83 & 7.67 \\
\hline
\end{tabular}

increasing levels of $\mathrm{NaCl}$ are correlated with higher $\mathrm{pH}$ values (Fig. 1). The $\mathrm{pH}$ values were decreased towards the end of ripening. Similar observations were reported by several authors $[1,8,19,25]$. Table I shows the average values of dry matter, fatin-dry matter, protein and salt-in-moisture of Beyaz cheese during ripening. Fat-in-dry matter and protein contents did not change during ripening. The highest values of dry matter and salt-in-moisture values were observed in the cheeses ripened in $18 \mathrm{~g}$ $\mathrm{NaCl} \cdot 100 \mathrm{~g}^{-1}$. The dry matter percentages are lower than those of the semi-hard cheeses. Normally, they must contain at least $40 \%$ dry matter in Turkish legislations and ripen for more than $60 \mathrm{~d}$; however, our goal was to produce soft-type Beyaz cheese for breakfast and short-term consumption. We restricted the ripening period to ca. $60 \mathrm{~d}$ and no deformation was observed in cheese blocks in that period. The brining phenomenon and the effect of increasing the ionic strength on the structure of the casein matrix can be explained as follows: when a cheese mould is placed in a brine, there is a net movement of $\mathrm{Na}^{+}$and $\mathrm{Cl}^{-}$ions from the brine into the cheese due to osmotic pressure difference between the cheese moisture and the brine. Moisture in cheese diffuses out through the cheese matrix until the osmotic pressure becomes equal. The migration of salt or water is impeded by the casein matrix due to its narrow pores. The loss of water is about twice the $\mathrm{NaCl}$ entering, proportional to their molecular sizes 


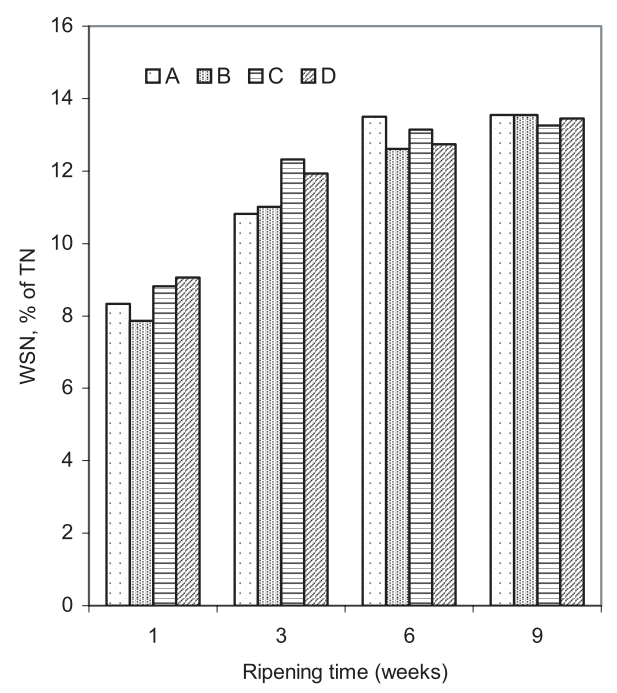

Figure 2. Changes in water-soluble nitrogen (WSN) of Beyaz cheeses ripened in brines of

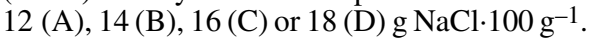

$[14,15]$. However, brine with high salt content may cause a rapid loss of water and shrinkage and decrease in porosity of the structure of the casein matrix. Consequently, the narrowed pores of the casein matrix impede the movement of salt and water [24].

\subsection{Proteolysis}

Proteolysis in Beyaz cheese was monitored by determining WSN and $12 \%$ TCA$\mathrm{SN}$ fractions and urea-PAGE patterns during ripening. The WSN fraction contains whey proteins, proteose-peptone, low molecular weight peptides derived from casein hydrolysis [26]. The concentration of $\mathrm{NaCl}$ did not significantly affect WSN contents of the cheeses $(P>0.05)$. The level of WSN increased rapidly from the 1 st wk to the 6th wk, followed by a slower increase after the 6th wk of the ripening period. The WSN percentage of total nitrogen of 9week cheeses was about $13 \%$ (Fig. 2). This may be due to the inhibitory effect of the salt on the activity of starter bacteria [15]. Cheeses ripened in brine $\mathrm{D}\left(18 \mathrm{~g} \mathrm{NaCl} \cdot 100 \mathrm{~g}^{-1}\right)$ had the lowest percentages of TCA-SN of total

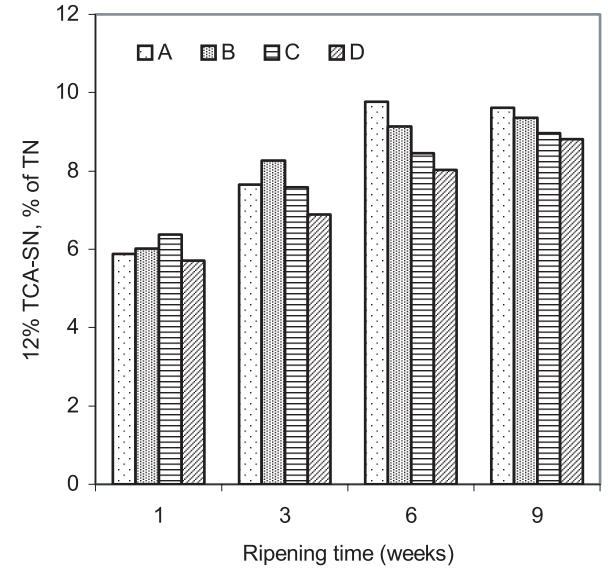

Figure 3. Changes of $12 \%$ trichloroacetic acidsoluble nitrogen (TCA-SN) of Beyaz cheeses ripened in brines of 12 (A), 14 (B), 16 (C) or 18 (D) $\mathrm{g} \mathrm{NaCl} \cdot 100 \mathrm{~g}^{-1}$.

nitrogen (Fig. 3). Significant differences among cheese samples were observed after the 3 rd week of ripening $(P<0.05)$. The level of TCA-SN increased significantly $(P<0.05)$ during ripening and was inversely proportional to the salt concentrations of the cheese as shown in Figure 3. These results are in agreement with the results of Al Otaibi and Wilbey [2,3].

Urea-PAGE electrophoretograms of the cheeses at 1 and 9 weeks of ripening are shown in Figure 4. In all experimental cheeses, $\alpha_{s 1}$-caseins were extensively degraded during ripening; however, no significant differences were noted among the experimental cheeses. The $\alpha_{s_{1} \text {-caseins were degraded }}$ more rapidly than $\beta$-caseins as in most bacterially ripened cheeses [12, 31]. Many peptides appeared with mobility higher than that of $\alpha_{\mathrm{s} 1}$-casein that can be attributed to $\alpha_{1}$-casein hydrolysis. The degradation products exhibited the same pattern in all four experimental cheeses and the intensities of these bands increased during ripening. Some weak bands were also observed in the region of $\gamma$-casein after 6 weeks of ripening. Densitometric evaluations of the electrophoretograms showed that $\alpha_{\mathrm{s} 1}$-casein in all cheeses significantly decreased during ripening (Fig. 5); however, the degradation of 


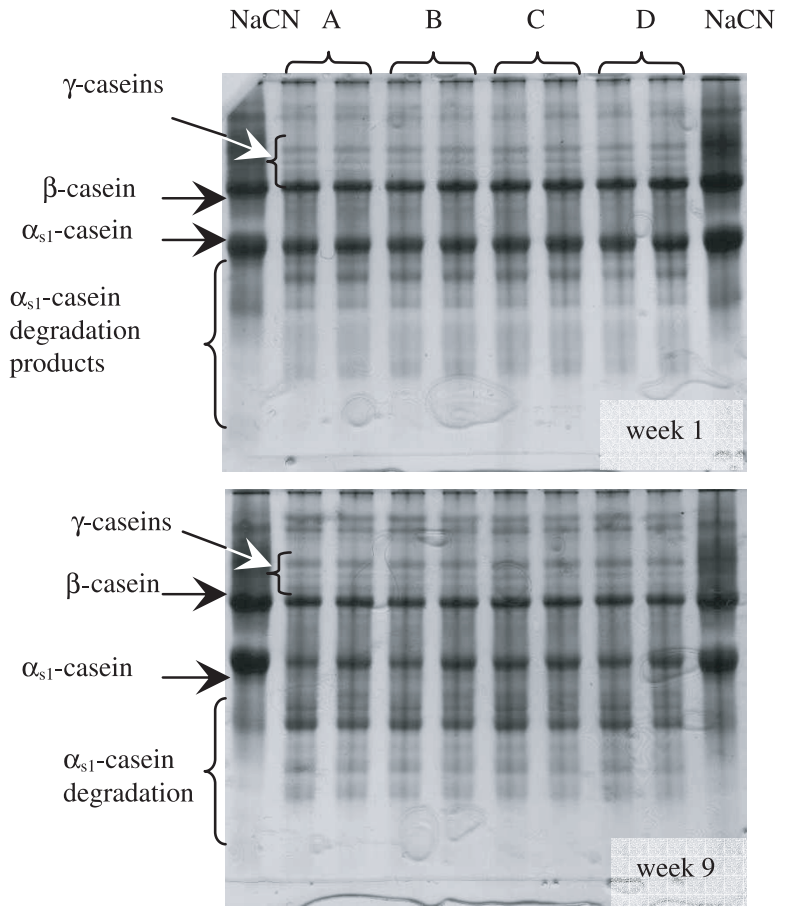

Figure 4. Urea-polyacrylamide gel electrophoresis of Beyaz cheese ripened in brines of 12 (A), 14 (B), 16 (C) or 18 (D) $g$ $\mathrm{NaCl} \cdot 100 \mathrm{~g}^{-1}$. $\mathrm{NaCN}=$ Sodium caseinate. Cheese samples were analysed after 1 (upper gel) and 9 (lower gel) weeks of ripening. $\alpha_{\mathrm{s} 1}$-casein was not significantly affected by the salt concentration at any stages of ripening. This is in agreement with the results of Kristiansen et al. [20], who reported that the different levels of salt content did not affect the hydrolysis of $\alpha_{\mathrm{s} 1}$-casein in a Danbo-type cheese. The percentages of $\beta$-casein (evaluated by densitometry) decreased during ripening and, in general, its levels were inversely related to the salt concentration. That is, increasing levels of salt are correlated with lower levels of $\beta$ casein degradation (Fig. 6). Densitometric values of $\beta$-casein in A, B, C and D cheeses were $26.1 \%, 27.5 \%, 28.1 \%$ and $27.6 \%$ at 1 week of ripening; and $18.4 \%, 20.0 \%$, $23.8 \%$ and $24.4 \%$ at 9 weeks of ripening, respectively. Breakdown of $\beta$-casein in cheeses A and B was significantly higher than in $\mathrm{C}$ and $\mathrm{D}(P<0.05)$ at 3,6 and 9 weeks of ripening. This could be partially explained by the inhibition effect of salt on hydrolysis of $\beta$-casein by rennet $[4,11]$.

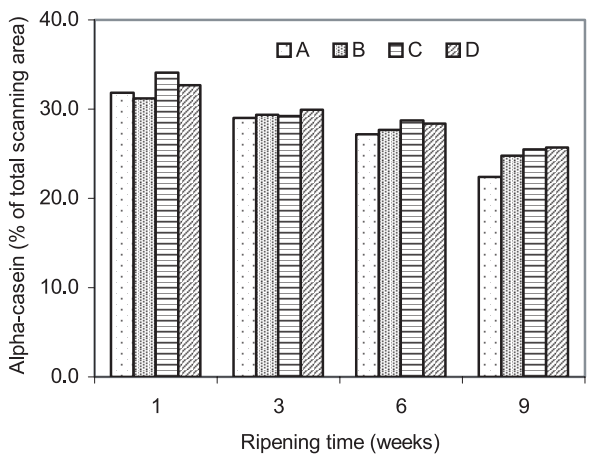

Figure 5. Hydrolysis of $\alpha_{\mathrm{s} 1}$-caseins of Beyaz cheeses ripened in brines of $12(\mathrm{~A}), 14(\mathrm{~B})$,

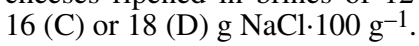

\subsection{Sensory evaluation and hardness}

No significant differences among the cheese samples were found regarding the appearance, body and texture and odour 
Table II. Sensory evaluation of Beyaz cheeses ripened in brines with different $\mathrm{NaCl}$ concentrations (Trials 1 and 2).

\begin{tabular}{|c|c|c|c|c|c|c|c|c|c|}
\hline \multirow{3}{*}{ Parameter } & \multirow{3}{*}{$\begin{array}{l}\text { Time } \\
(\mathrm{wks})\end{array}$} & \multicolumn{8}{|c|}{ Cheeses } \\
\hline & & \multicolumn{2}{|c|}{$\mathrm{A}^{1}$} & \multicolumn{2}{|c|}{$\mathrm{B}^{1}$} & \multicolumn{2}{|c|}{$\mathrm{C}^{1}$} & \multicolumn{2}{|c|}{$\mathrm{D}^{1}$} \\
\hline & & $\mathrm{T} 1$ & $\mathrm{~T} 2$ & $\mathrm{~T} 1$ & $\mathrm{~T} 2$ & $\mathrm{~T} 1$ & $\mathrm{~T} 2$ & $\mathrm{~T} 1$ & $\mathrm{~T} 2$ \\
\hline \multirow{4}{*}{$\begin{array}{l}\text { Appearance } \\
(0-20)\end{array}$} & 1 & 18.6 & 20.0 & 19.8 & 18.6 & 20.0 & 18.9 & 20.0 & 20.0 \\
\hline & 3 & 16.4 & 16.7 & 18.3 & 16.7 & 20.0 & 16.9 & 18.7 & 17.7 \\
\hline & 6 & 19.4 & 18.7 & 17.1 & 18.4 & 19.0 & 18.4 & 19.7 & 19.3 \\
\hline & 9 & 17.6 & 17.2 & 17.6 & 18.9 & 17.6 & 18.9 & 17.4 & 18.7 \\
\hline \multirow{4}{*}{$\begin{array}{l}\text { Body and Texture } \\
(0-35)\end{array}$} & 1 & 31.6 & 29.0 & 30.9 & 29.6 & 29.4 & 31.4 & 31.9 & 29.4 \\
\hline & 3 & 27.4 & 27.6 & 30.7 & 28.5 & 26.9 & 31.1 & 29.4 & 29.6 \\
\hline & 6 & 31.6 & 31.6 & 29.6 & 27.7 & 29.5 & 29.7 & 31.7 & 30.6 \\
\hline & 9 & 31.8 & 30.6 & 30.4 & 27.3 & 27.0 & 30.0 & 28.3 & 31.3 \\
\hline \multirow{4}{*}{$\begin{array}{l}\text { Odour } \\
(0-10)\end{array}$} & 1 & 10.0 & 9.6 & 10.0 & 9.8 & 10.0 & 9.4 & 10.0 & 9.3 \\
\hline & 3 & 8.6 & 9.3 & 9.3 & 8.6 & 9.4 & 9.2 & 9.1 & 8.7 \\
\hline & 6 & 9.8 & 9.4 & 9.5 & 9.7 & 9.7 & 9.5 & 9.5 & 9.9 \\
\hline & 9 & 9.6 & 9.4 & 8.4 & 9.1 & 9.4 & 8.4 & 9.4 & 8.6 \\
\hline \multirow{4}{*}{$\begin{array}{l}\text { Flavour } \\
(0-35)\end{array}$} & 1 & 32.6 & 30.4 & 32.6 & 31.4 & 30.7 & 26.6 & 28.1 & 25.9 \\
\hline & 3 & 27.1 & 28.7 & 31.1 & 28.6 & 27.9 & 27.7 & 24.0 & 26.7 \\
\hline & 6 & 32.6 & 30.5 & 26.6 & 24.0 & 27.0 & 25.5 & 21.1 & 27.1 \\
\hline & 9 & 27.3 & 31.1 & 28.1 & 25.7 & 20.9 & 23.4 & 23.3 & 25.7 \\
\hline \multirow[t]{4}{*}{ Total Scores } & 1 & 91.2 & 90.6 & 92.1 & 90.6 & 85.4 & 91.0 & 84.6 & 90.0 \\
\hline & 3 & 79.5 & 82.3 & 86.9 & 84.9 & 80.7 & 88.5 & 83.1 & 80.8 \\
\hline & 6 & 93.4 & 90.4 & 78.5 & 84.1 & 84.6 & 83.7 & 84.4 & 82.7 \\
\hline & 9 & 85.7 & 88.7 & 82.1 & 83.4 & 78.7 & 76.9 & 78.4 & 82.1 \\
\hline \multirow{4}{*}{$\begin{array}{l}\text { Hardness } \\
(\mathrm{mm} / 5 \mathrm{~s})\end{array}$} & 1 & 11.4 & 12.0 & 10.0 & 11.1 & 9.5 & 9.0 & 9.3 & 8.1 \\
\hline & 3 & 10.7 & 11.9 & 10.7 & 9.5 & 9.5 & 9.1 & 10.4 & 8.9 \\
\hline & 6 & 9.5 & 11.3 & 10.9 & 9.3 & 9.4 & 9.8 & 9.3 & 10.4 \\
\hline & 9 & 9.9 & 8.3 & 9.1 & 8.5 & 9.9 & 9.3 & 9.4 & 10.1 \\
\hline
\end{tabular}

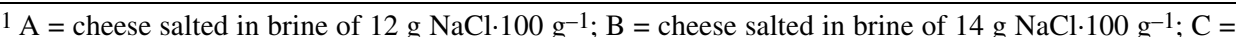
cheese salted in brine of $16 \mathrm{~g} \mathrm{NaCl} 100 \mathrm{~g}^{-1} ; \mathrm{D}=$ cheese salted in brine of $18 \mathrm{~g} \mathrm{NaCl} \cdot 100 \mathrm{~g}^{-1}$. T: trial.

scores (Tab. II). However, flavour and total sensory scores were significantly influenced by the use of different concentrations of $\mathrm{NaCl}$. The cheeses ripened in $12 \mathrm{~g}$ $\mathrm{NaCl} \cdot 100 \mathrm{~g}^{-1}$ solution had the best score for flavour and the best total scores after 6 weeks of ripening, while the cheeses ripened in $16 \mathrm{~g} \mathrm{NaCl}^{\circ} 100 \mathrm{~g}^{-1}$ or $18 \mathrm{~g} \mathrm{NaCl} \cdot 100 \mathrm{~g}^{-1}$ solutions had the lowest. Hardness values, which indicate the texture of the cheeses, decreased with increasing $\mathrm{NaCl}$ concentration and ripening period until 6 weeks of ageing (Tab. II). The cheeses ripened in a $12 \mathrm{~g} \mathrm{NaCl} \cdot 100 \mathrm{~g}^{-1}$ brine had the highest hardness values up to 6 weeks of ripening, probably due to a higher extent of proteolysis [13, 22]. However, at the 9th week,

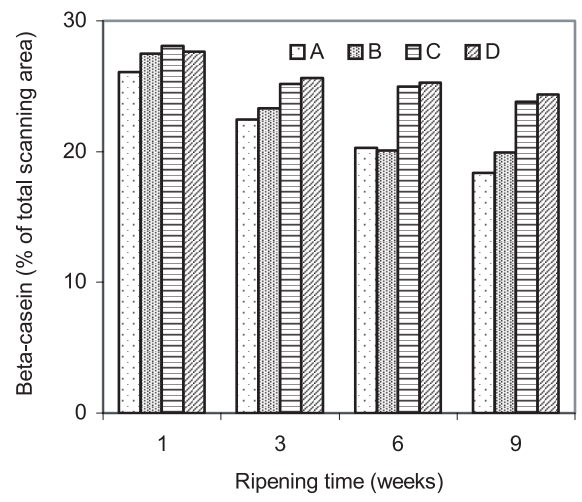

Figure 6. Hydrolysis of $\beta$-caseins of Beyaz cheeses ripened in brines of 12 (A), 14 (B), 16 (C)

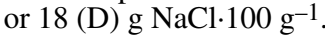


hardness $(\mathrm{mm} / 5 \mathrm{~s})$ was similar in all four cheeses.

\section{CONCLUSION}

The results obtained from this study indicate that a brine of $12 \mathrm{~g} \mathrm{NaCl} \cdot 100 \mathrm{~g}^{-1}$ (cheese A) was suitable for Beyaz cheese manufacture. The WSN fractions and ureaPAGE patterns of the cheeses (except for $\beta$-casein degradation) showed no significant differences among cheeses ripened in the four different brines. However, the TCA-SN fractions of the cheeses decreased with increasing $\mathrm{NaCl}$ concentrations. The cheeses ripened in $12 \mathrm{~g} \mathrm{NaCl} \cdot 100 \mathrm{~g}^{-1}$ brine had the best organoleptic scores. The effect of different concentrations of $\mathrm{NaCl}$ on the microbial groups, peptide profiles, amino acid concentration, rheology and microstructure of Beyaz cheeses during ripening needs to be investigated.

Acknowledgements: This work was partially funded by the Scientific Research Projects Unit, Cukurova University, Adana, Turkey. The authors would like to thank M. Curuk, H. Gulsev and E. Karli for their helpful technical assistance and for sharing their experience during cheese-making and cheese analysis.

\section{REFERENCES}

[1] Akbulut N., Gonc S., Kinik O., Uysal H., Akalin S., Kavas G., Bazi tuzlama yontemlerinin Beyaz peynir uretiminde uygulanabilirligi ve peynir kalitesi etkileri uzerinde bir arastirma. 2-kimyasal ozelliklere etkileri, Ege Univ. Ziraat Fak. Derg. 33 (1996) 17-24.

[2] Al Otaibi M.M. Wilbey R.A., Effect of temperature and salt on the maturation of whitesalted cheese, Int. J. Dairy Technol. 57 (2004) 57-63.

[3] Al Otaibi M.M., Wilbey R.A., Effect of chymosin and salt reduction on the quality of ultrafiltrated white-salted cheese, J. Dairy Res. 72 (2005) 234-242.

[4] Alichanidis E., Anifantakis E., Polychroniadou A., Nanou M., Suitability of some microbial coagulants for Feta cheese manufacture, J. Dairy Res. 51 (1984) 141-147.

[5] Andrews A.T., Proteinases in normal bovine milk and their action on the caseins, J. Dairy Res. 50 (1983) 45-55.
[6] Ardo Y., Polychroniadou A., Laboratory Manual for Chemical Analysis of Cheese, Office for Official Publications of the European Communities, Luxembourg, 1999.

[7] Blakesley R.W., Boezi J.A., A new staining technique for proteins in polyacrilamide gels using Coomasie Brilliant Blue G250, Anal. Biochem. 82 (1977) 580-581.

[8] Demiryol I., Inek, koyun ve keci sutleriyle yapilan ve farkli sicakliklarda olgunlastirilan Beyaz peynirlerin ozellikleri uzerinde arastirmalar, Ph.D. Thesis, Ege University, Izmir, Turkey, 1983

[9] Fenelon M.A., Guinee T.P., Primary proteolysis and textural changes during ripening in Cheddar cheese manufactured to different fat contents, Int. Dairy J. 10 (2000) 151-155.

[10] Fox P.F., Proteolysis during cheese manufacture and ripening, J. Dairy Sci. 72 (1989) 1379-1400.

[11] Fox P.F., Walley B.F., Influence of sodium chloride on the proteolysis of casein by rennet and pepsin, J. Dairy Res. 38 (1971) 165-170.

[12] Fox P.F., Law J., McSweeney P.L.H., Wallace J., Biochemistry of cheese ripening, in: Fox P.F. (Ed.), Cheese: Chemistry, Physics and Microbiology, Chapman and Hall, London, UK, 1993, pp. 389-438.

[13] Fox P.F., Guinee T.P., Cogan T.M., McSweeney P.L.H., Fundamentals of Cheese Science, Aspen Publication, London, UK, 2000.

[14] Guinee T.P., Salting and role of salt in cheese, Int. J. Dairy Technol. 57 (2004) 99-109.

[15] Guinee T.P., Fox P.F., Salting in cheese: Physical, chemical and biological aspects, in: Fox P.F. (Ed.), Cheese: Chemistry Physics and Microbiology, Elsevier Applied Science, London, UK, 1987, pp. 251-297.

[16] Hayaloglu A.A., Guven M., Fox P.F., Microbiological, biochemical technological properties of Turkish White cheese "Beyaz Peynir", Int. Dairy J. 12 (2002) 635-648.

[17] IDF, Cheese and Processed Cheese: Determination of the total solids contents. Reference Method 4A, International Dairy Federation, Brussels, 1982.

[18] IDF, Milk: Determination of the nitrogen (Kjeldahl Method) and calculation of the crude protein Content. IDF Standard 20B, International Dairy Federation, Brussels, 1993.

[19] Kocak C., Gursel A., Ergul E., Farkli asitlikteki salamurada bekletmenin peynire tuz gecisi uzerine etkisi, Gida 15 (1990) 211-215. 
[20] Kristiansen K.R., Deding A.S., Jensen D.F., Ardo Y., Quvist K.B., Influence of salt content on ripening of semi-hard round eyed cheese of Danbo-type, Milchwissenschaft 54 (1999) 19-23.

[21] Kuchroo C.N., Fox P.F., Soluble nitrogen in Cheddar cheese: Comparison of extraction procedures, Milchwissenschaft 37 (1982) 331335.

[22] Lawrence R.C., Creamer L.K., Gilles J., Texture development during cheese ripening, J. Dairy Sci. 70 (1987) 1748-1760.

[23] Marshall R.T., Standard Methods For The Examination of Dairy Products, American Public Health Association, Washington DC, USA, 1993.

[24] Melilli C., Barbano D.M., Licitra G., Tumino G., Farina G., Carpino S., Influence of presalting and brine concentration on salt uptake by Ragusano cheese, J. Dairy Sci. 86 (2003) 1083-1100.

[25] Patir B., Salamura Beyaz Peynirin olgunlasmasi sirasinda enterotoksijenik koagulaz pozitif Staphylococcus aureus'un yasam sureleri ile mikrobiyolojik ve kimyasal niteliklerinde meydana gelen degismeler, Doga Turk Vet. Hay. Derg. 11 (1987) 59-71.

[26] Pavia M., Trujillo A.J., Guamis, B., Ferragut, V., Proteolysis in Manchego-type cheese sal- ted by brine vacuum impregnation, J. Dairy Sci. 83 (2000) 1441-1447.

[27] Polychroniadou A., Michaelidou A., Paschaloudis N., Effect of time, temperature and extraction method on the trichloroacetic acid-soluble nitrogen of cheese, Int. Dairy J. 9 (1999) 559-568.

[28] Steel R.G.D., Torrie J.H., Principles and Procedures of Statistics, McGraw Hill, New York, USA, 1980.

[29] TSE, Beyaz Peynir, TS 591. Turkish Standards Institute, Ankara, Turkey, 1995.

[30] Uraz T., Gencer N., Beyaz peynirlerde kalip buyuklugu ve salamura miktarinin tuz alimi uzerine etkisi, Tr. J. Agric. For. 24 (2000) 621-628.

[31] Visser F.M.W., De Groot-Mostert A.E.A., Contribution of enzymes from rennet, starter bacteria and milk to proteolysis and flavour development in Gouda cheese. 4. Protein breakdown: A gel electrophoretic study, Neth. Milk Dairy J. 31 (1977) 247-264.

[32] Visser S., Proteolytic enzymes and their relation to cheese ripening and flavor: an overview, J. Dairy Sci. 76 (1993) 329-350.

[33] Yildiz F. Kocak C., Karacabey A., Gursel A., Turkiye'de kaliteli salamura Beyaz peynir uretim teknolojisinin belirlenmesi, Doga Turk Vet. Hay. Derg. 13 (1989) 384-392. 